2. Орлова О.Н., Сорокопудова О.А. Виды очитковых (Crassulaceae) для озеленения города Белгорода / Научные ведомости Белгородского государственного университета. - Серия: Естественные науки. - 2010. - Т. 9. - С. 45-48.

3. Верещагина И.В., Долганова 3.В. Зимующие многолетники, рекомендуемые для Алтайского края. Методические рекомендации. / Сиб. отд-ние ВАСХНИЛ, НИИСС. - Новосибирск. - 1985. - 36 с.

4. Методика государственного испытания сельскохозяйственных культур: Декоративные культуры. - М.: Колос, 1968. - Вып 6. - 223 с.

5. Карписонова Р.А. Травянистые растения широколиственных лесов. - М.: «Наука», 1985. - С. 56-62.

\title{
Изменчивость шишек и семян клонов сосны кедровой сибирской (Pinus sibirica Du Tour) в Краснообске
}

Лихенко Н.Н.*, к.с.-х.н., в.н.с.; Чудная А.П., агроном 1 категории; Капко Т.Н., м.н.с.

Сибирский научно-исследовательский институт растениеводства и селекиии - филиал ИЦиГ СО РАН, Новосибирск, Россия.

*e-mail: lihenko.n@yandex.ru

Приведены данные, характеризующие размеры шишек и семян клонов плюсовых деревьев сосны кедровой сибирской, произрастающих на территории дендропарка СибНИИРС - филиала ИЦиГ СО РАН. По совокупности признаков клонов выделился № 96, поскольку на нем формировались наиболее крупные и полнозернистые шишки с наибольшим выходом семян по массе (19,9 г) и массе 1000 семян (256,7 г).

Ключевые слова: сосна кедровая сибирская, клон, иишка.

\section{Variability of cones and seeds at clones of Siberian cedar pine in Krasnoobsk}

Likhenko N.N. *, Chudnaya A.P., Kapko T.N.

SibRIPP\&B - branch ICG SB RAS, Novosibirsk, Russia.

*e-mail: lihenko.n@yandex.ru

The data characterizing the sizes of cones and seeds of clones of plus trees of Siberian cedar pine, which are grows in the arboretum of SibRIPP\&B-branch ICG SB RAS, are provided. According to the totality of features, clone No. 96 stood out. It formed the largest and most full-grain cones with the highest seed yield by weight (19.9 g) and 1000 seeds $(256.7 \mathrm{~g})$.

Key words: Siberian cedar pine, clone, cone.

Сосна кедровая сибирская - это одна из наиболее значимых в хозяйственном отношении орехоплодных хвойных пород, представляющей интерес в качестве источника ценной древесины и продуктов пищевого и технического 
назначения. Кроме того, кедр сибирский отличается высокой декоративностью. Особый интерес представляют его семена - кедровые орехи, содержащие порядка 60 \% жира, богатые витаминами и отличающиеся очень высокой пищевой ценностью и усвояемостью [1]. Известно, что несколько хороших урожаев семян кедра сибирского полностью окупают стоимость его древесины [2]. В связи с чем особый интерес представляет его выращивание в культуре и изучение с целью отбора на семенную продуктивность.

Исследования проведены в условиях дендропарка СибНИИРС - филиала ИЦиГ СО РАН, в клоновом архиве, при создании которого были использованы привои с плюсовых деревьев кедра сибирского (Pinus sibirica Du Tour), отобранные и аттестованные в Колыванском лесхозе Новосибирской области. Клоновый архив был заложен весной 1990 г. на площади 1 га с размещением по садовому типу для обеспечения перекрестного опыления. 147 растений расположены рядами с запада на восток, поперек господствующих ветров высажена лесозащитная полоса из сосны обыкновенной (Pinus sylvestris L.).

В ходе эксперимента у 13 клонов сосны кедровой сибирской было изучено плодоношение в урожайный год. Сбор зрелых шишек проведен 1 сентября 2019 г. Раздельно собранные образцы пронумерованы в соответствии номеру клона. Просушены при комнатной температуре и влажности в течение двух месяцев. Собранный материал позволил провести анализ количественных параметров шишек и семян (длина шишек, диаметр в средней части, масса шишек, количество семян в шишке, масса семян в шишке). Крупность шишек определяли в соответствии с классификацией, предложенной Л.Ф. Правдиным [3]: крупные - более 8 см, средние - 6-8 см, мелкие - менее 6 см. Геометрическая форма была определена инструментально с использованием коэффициента формы (по отношению ширины к длине): коэффициент менее 0,80 - шишки цилиндрические, 0,81-0,90 - яйцевидные, более 0,90 - округлые. По числу семян в шишках делятся на многосемянные (120 шт. и более) и малосемянные (50 шт. и менее) [4]. За основу брали шишку, сформированную у кедра сибирского в таежных условиях, длиной от 5 до 13 см, диаметром от 4 до 8 см [5], весом от 50 до 58 г, с массой 1000 шт. семян в пределах 200-250 г [6]. Для оценки уровня изменчивости количественных признаков использовали шкалу, разработанную С.А. Мамаевым [7].

Целью настоящей работы послужил морфометрический анализ шишек и семян 29-летних клонов Pinus sibirica Du Tour, произрастающих в дендропарке СибНИИРС - филиала ИЦиГ СО РАН.

В результате исследования биометрических показателей шишек и семян клонов сосны кедровой сибирской (таблица) установлено, что средняя

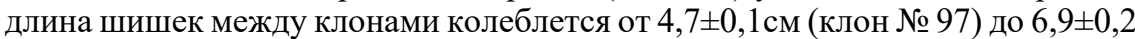
см (клон № 96). Уровень изменчивости длины шишек в клонах преимущественно низкий (CV 6,4-13,6 \%) (таблица). В соответствии с классификацией, предложенной Л.Ф. Правдиным [3], шишки формируются от мелких до средних размеров. Диаметр шишки колеблется от 3,6 0,1 см (клон № 24) до $4,7 \pm 0,1$ см (клоны №№ 96, 111), уровень изменчивости в пределах нижней нормы варьирования. Форма шишек зависит от отношения ее ширины к 
длине [4]. Шишки исследуемых образцов имеют преимущественно цилиндрическую форму. Клон № 97 имеет яйцевидную форму шишек. Средняя масса шишек клона № 96 (48,3 33,2 г) превышает весовые параметры шишек по всем клонам от 1,3 до 2,4 раза. С увеличением линейных размеров шишки увеличивается количество семян и масса семян. По числу семян выделяются

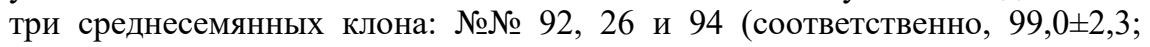
$99,9 \pm 3,2$ и $111,4 \pm 4,3$ шт. при среднем уровне варьирования), по массе семян

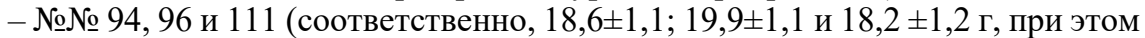
уровень изменчивости признака был повышенный). Масса 1000 шт. определяет качество семян, показывает запас питательных веществ, всхожесть, пищевую ценность. Показатели массы 1000 семян интродуцированных клонов кедра сибирского в исследуемом урожайном 2019 г. варьировали от $200,7 \pm 2,9$ г (клон № 97) до 256,7 $\pm 5,7$ г (клон № 96), что близко к показателям естественного ареала $[5,6]$.

Распределение семян в шишке по категориям (рисунок) характеризуется наличием нормальных семян (полнозернистых), недоразвитых, дефектных, прекративших свое развитие на различных стадиях. Причины дефективности могут быть различны. Среди исследуемых клонов только у № 89 доля недоразвитых семян составила $64,4 \%$, дефектных $-5,7 \%$. Наибольшее число нормальных семян в шишке (70,6 $\pm 3,9$ шт.) наблюдалось у клона № 96, полнозернистость (доля выполненных семян в шишке) составила 73,9 \%.

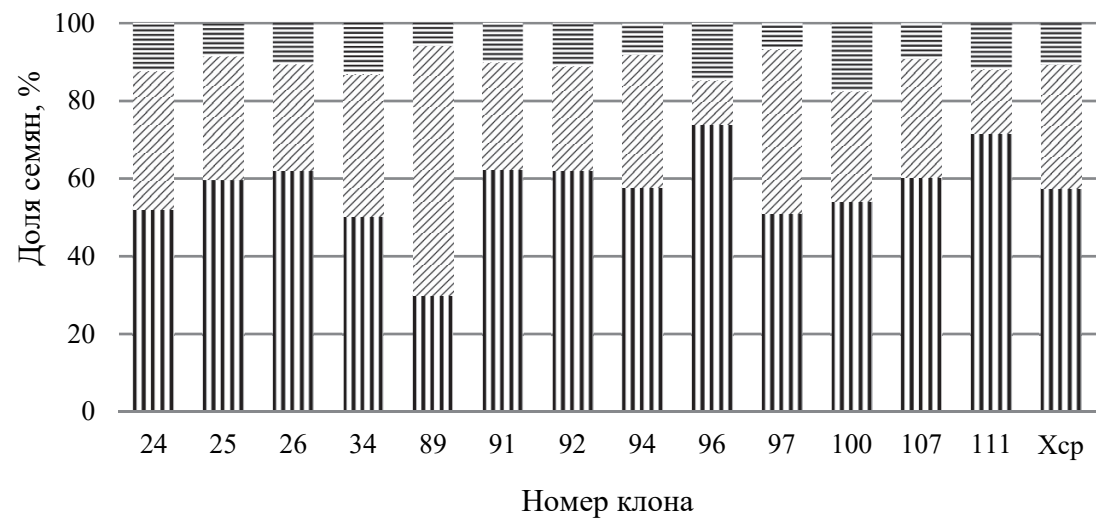

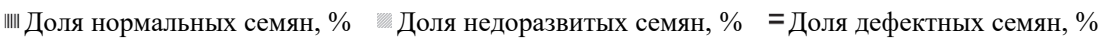

Рисунок - Распределение семян в шишке по категориям: нормальные (нормально развитые оплодотворенные семяпочки); недоразвитые (неоплодотворенные семяпочки и погибшие до оплодотворения); дефектные (пустые, гнилые, беззародышевые) [6]. 


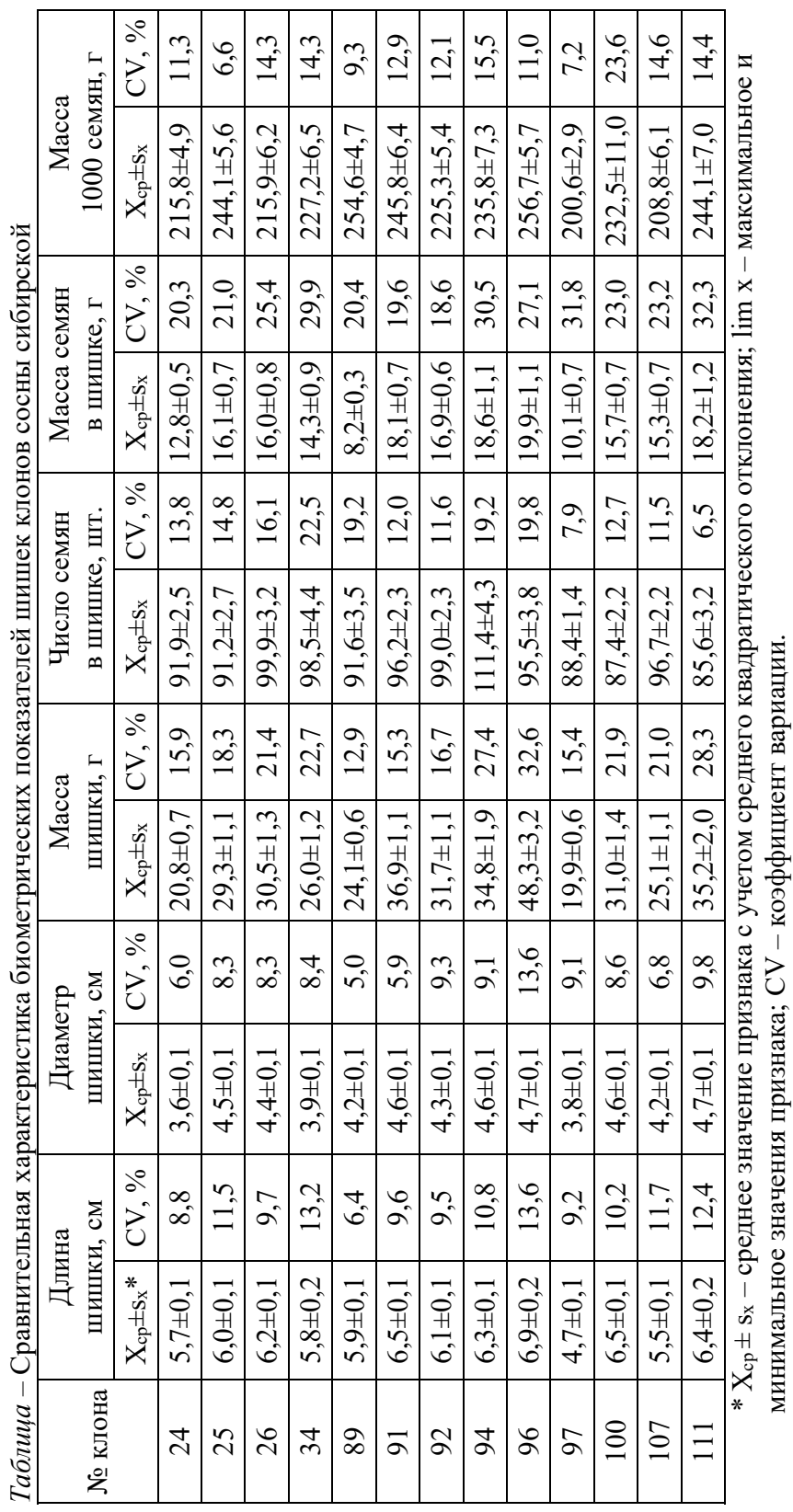


Заключение. В ходе изучения 13 интродукцированных клонов Pinus sibirica Du Tour установлено, что они формируют шишки и семена с размерами, близкими к средним показателям, характерным для естественных условий. По результатам оценки элементов продуктивности установлено, что в качестве наиболее привлекательных образцов можно отметить клоны: № 96 по длине и ширине шишки (6,9 и 4,7 см), по массе шишки (48,3 г), по массе семян в шишке (19,9 г), по массе 1000 семян (256,7 г), и № 94 - по числу зерен в шишке (111,4 шт.), по массе семян в шишке $(18,6$ г). По совокупности признаков среди исследованных клонов выделился № 96, поскольку на нем формировались наиболее крупные и полнозернистые шишки с наибольшим выходом семян по массе и массе 1000 шт. Таким образом, его можно считать наиболее пригодным для дальнейшего изучения в селекции, а также для сбора прививочного материала с целью создания прививочной плантации сосны сибирской кедровой.

Благодарности: Работа поддержана бюджетным проектом ИЦиГ СО PAH № 0324-2019-0039-C-01.

\section{Список литературы}

1. Ефремов А.А. Перспективы малотоннажной переработки кедровых орехов в продукты пищевого и технического назначения / А.А. Ефремов // Химия растительного сырья. - 1998. - № 3. - С. 83-86.

2. Земляной, А.И. О создании постоянной семенной базы кедра сибирского в Ханты-Мансийском округе (ХМАО - Юрга) / А.И. Земляной, В.И. Барановский // Лесное хозяйство. - 2008. - № 5. - С. 34-35.

3. Правдин Л.Ф. Селекция и семеноводство кедра сибирского / Л.Ф. Правдин // Плодоношение кедра сибирского в Восточной Сибири. М.: АН СССР, 1963. - С. 5-21.

4. Братилова Н.П. Биология и формовое разнообразие сосны кедровой сибирской / Н.П. Братилова, Р.Н. Матвеева, О.Ф. Буторова // Экопотенциал. - 2014. - №1. C. $120-127$.

5. Бех И.А. Сибирское чудо-дерево / И.А. Бех, И.В. Таран // Новосибирск: Наука, 1979. - 126 c.

6. Некрасова, Т.П. Биологические основы семеношения кедра сибирского / Т.П. Некрасова. - Новосибирск, 1972. - 273 с.

7. Мамаев С.А. Формы внутривидовой изменчивости древесных растений / С.А. Мамаев. - М.: Наука, 1973. -284 с. 